\title{
Relationship between Body Weight and Linear Body Measurements in Japanese Quail (Coturnix coturnix japonica)
}

\author{
V. Ojo", T. R. Fayeye, K. L. Ayorinde, and H. Olojede \\ Animal Genetics and Breeding Unit, Department of Animal Production, University of Ilorin, \\ P.M.B. 1515, Ilorin, Kwara State, Nigeria
}

Received 9 September 2013, accepted in revised form 24 December 2013

\begin{abstract}
A total of 108 two-weeks-old Japanese quail chicks were used to study the relationship between body weight and linear measurements and to predict body weight from linear measurements of body length (BL), body girth (BG), wing length (WL), shank length (SL), shank diameter (SD) and drum stick (DS).The results showed that the mean quail birds' body weights were $35.23 \mathrm{~g}$ and $143.78 \mathrm{~g}$, at $2^{\text {nd }}$ and $8^{\text {th }}$ weeks, respectively. Body weight gain was increased between 2 and 6 weeks of age and thereafter decreased with advancing age. Female birds were significantly $(P<0.05)$ heavier than those of male counterpart at $6^{\text {th }}$ and $8^{\text {th }}$ weeks of age. Significantly positive correlations $(P<0.01)$ were obtained between body weight and body measurements at $2^{\text {nd }}, 4^{\text {th }}$ and $8^{\text {th }}$ weeks. The best correlation was obtained between body weight and body girth at the $2^{\text {nd }}$ week of age $(0.70)$. The estimates of coefficient of determination and predictive equations show that body weight in Japanese quail is linearly related to body measurements especially with body girth and body length. The study shows that it is possible for breeders to use BG and BL as criteria for assessment and early selection of Japanese quail for body weight.
\end{abstract}

Keywords: Japanese quail; Body weight; Linear measurements; Correlation

(c) 2014 JSR Publications. ISSN: 2070-0237 (Print); 2070-0245 (Online). All rights reserved.

doi: http://dx.doi.org/10.3329/jsr.v6i1.16368 J. Sci. Res. 6 (1), 175-183 (2014)

\section{Introduction}

Japanese quail is the smallest farmed avian specie for egg and meat [1] and it is becoming increasingly important in the Nigerian poultry industry [2]. Apart from its conventional use as a laboratory animal [3,4], Japanese quail has the potential to serve as an excellent and cheap source of animal protein [5]. The high prolificacy and hardy nature of the bird $[6,7]$ as well as the recent discovery of the health benefits of its egg, have made rearing of Japanese quail suitable for the resource poor tropical Sub-Saharan African countries.

Body weight, body conformation and yield are important traits to poultry breeders and processors [8]. Body weight plays an important role in determining several other

*Corresponding author: ojo_victoria@yahoo.com 
economic characteristics in farm animals [9]. It is an important attribute as it forms the basis for assessing growth, feed efficiency and also in making economic and market decisions in farm animals [10]. Maciejowski and Zeiba [11] observed positive correlations between body weight and a number of linear body measurements.

The indirect method of estimating body weight using body measurements has been reported to be practical, faster, easier, and cheaper approach, especially in the rural areas where the resources are insufficient and the acquisition of expensive sensitive weighing scale is unaffordable [12]. The shank length and diameter are important indicators of leg development, while body girth and length which are good indicators of breast development. Estimates of the relationship between body weight and these linear measurements is not only important in developing predictive equations, it could also be employed in genetic improvement strategies to achieve an optimum combination of body weight and good conformation [13].

The main objective of this study is to examine the relationship between body weight and linear body measurements in Japanese quail reared under the Nigeria environmental conditions and to develop regression equations for predicting body weight from linear measurements at different ages.

\section{Materials and Methods}

The experiment was conducted at the Poultry unit of the Department of Animal Production, Faculty of Agriculture, University of Ilorin, Ilorin. All experiments were implemented in accordance with Institutional guidelines on the care and use of animals for scientific studies, and in compliance with generally accepted rules of best practice worldwide.

\subsection{Origin and management of experimental birds}

A total of one hundred and eight (108) two weeks old Japanese quail of mixed sex (55 males and 53 females) were obtained from a random-bred population that has been maintained already by the department for three generations [14]. The breeding stock was initially developed at the National Veterinary Research Institute (NVRI) station, Vom (Jos, Nigeria) from fertile eggs obtained from the Republic of Benin in 1992. The selected birds have been previously tagged on their wings and kept in brooding pen at day-old. Feed and water were supplied ad-libitum throughout the six (6) weeks period of the experiment [14]. Standard prophylactic procedures were also followed.

\subsection{Data collection}

Body weight (g): Body weight was recorded to two decimal places using a sensitive weighing scale (Scout II brand). 
Body length $(\mathrm{cm})$ : Body length was taken with a measuring tape stretched from bird's nasal opening, along its gently stretched neck and back, to the tip of its pygostyle.

Body girth $(\mathrm{cm})$ : Body girth was taken when a measuring tape is looped round the region of the breast under the wing.

Wing length $(\mathrm{cm})$ : Wing length was as the distance from the humerus-coracoid junction to the distal tip of the phalange digits, using a measuring tape.

Shank length $(\mathrm{cm})$ : The shank length was taken as the distance between the foot pad and the hock joint, measured by a set of Vernier calipers.

Shank diameter $(\mathrm{cm})$ : Shank diameter was taken as the width of the shank measured by the use of a Venier calipers.

Drum stick $(\mathrm{cm})$ : Drum stick was taken as the distance from the tip of hock to the ball joint of femur, measured by the use of a measuring tape.

\subsection{Statistical analysis:}

Data were subjected to analysis of variance (ANOVA) appropriate for a Completely Randomized Design and significantly different means $(P<0.05)$ were further separated by the use of Duncan's Multiple Range procedure option in [15] statistical package. Correlation, linear and multiple regression analysis between body weight and the various body size parameters were also determined. The coefficient of determination $\left(\mathrm{R}^{2}\right)$ for each parameter in the regression equations was determined to show the relative contribution of each body measurement to the body weight of Japanese quail at different ages. The following linear regression equation was used to predict body weight from linear measurements.

$$
Y=a+b x
$$

where $Y=$ body weight or dependent variable, $a=$ constant in the regression equation, $b=$ regression coefficient and, $x=$ various body measurements

\section{Results}

The mean $( \pm$ SEM $)$ and the coefficients of variation of body weight and linear measurements at different ages are presented in Table 1. The data indicated a progressive increase in body weight gain and linear measurements over the eight weeks period. Mean body weight increased from $35.23 \mathrm{~g}$ at 2 weeks of age to $143.78 \mathrm{~g}$ at 8 weeks of age. The highest body weight gain occurred between two and four weeks of age $(58.44 \mathrm{~g})$. Body length increased from $11.84 \mathrm{~cm}$ at week two to $19.45 \mathrm{~cm}$ at week eight. Body girth increased from $8.02 \mathrm{~cm}$ at week 2 to $13.67 \mathrm{~cm}$ at week 8 . 
Table 1 . Mean of body weight and linear measurements $( \pm \mathrm{SD})$ of Japanese quail at different.

\begin{tabular}{|c|c|c|c|c|c|c|c|c|}
\hline & $2^{\text {nd }}$ week & & $4^{\text {th }}$ week & & $6^{\text {th }}$ week & & $8^{\text {th }}$ week & \\
\hline Traits & Mean \pm S.E & C.O.V & Mean \pm S.E & C.O.V & Mean \pm S.E & C.O.V & Mean \pm S.E & C.O.V \\
\hline $\mathrm{BW}(\mathrm{g})$ & $35.23 \pm 0.61$ & 17.85 & $93.67 \pm 1.18$ & 13.09 & $138.95 \pm 1.81$ & 13.54 & $143.78 \pm 1.82$ & 13.14 \\
\hline $\mathrm{BL}(\mathrm{cm})$ & $11.84 \pm 0.08$ & 7.26 & $17.40 \pm 0.07$ & 4.43 & $19.24 \pm 0.13$ & 6.86 & $19.45 \pm 0.07$ & 3.95 \\
\hline $\mathrm{BG}(\mathrm{cm})$ & $8.20 \pm 0.07$ & 9.27 & $11.92 \pm 0.08$ & 6.96 & $13.70 \pm 0.06$ & 4.82 & $13.67 \pm 0.06$ & 4.75 \\
\hline WLcm) & $5.95 \pm 0.08$ & 13.45 & $8.79 \pm 0.05$ & 6.26 & $8.70 \pm 0.05$ & 6.44 & $8.90 \pm 0.46$ & 5.43 \\
\hline $\mathrm{SL}(\mathrm{cm})$ & $2.31 \pm 0.03$ & 12.55 & $2.95 \pm 0.02$ & 7.46 & $2.99 \pm 0.01$ & 5.02 & $2.96 \pm 0.01$ & 5.07 \\
\hline $\mathrm{SD}(\mathrm{cm})$ & $0.32 \pm 0.004$ & 12.50 & $0.41 \pm 0.002$ & 4.88 & $0.43 \pm 0.003$ & 6.98 & $0.44 \pm 0.003$ & 6.82 \\
\hline $\mathrm{DS}(\mathrm{cm})$ & $3.04 \pm 0.03$ & 10.20 & $4.78 \pm 0.05$ & 9.83 & $5.15 \pm 0.02$ & 4.47 & $5.16 \pm 0.02$ & 4.65 \\
\hline
\end{tabular}

BW- body weight; BL- body length; BG-body girth; WL-wing length; SL-shank length; SD- shank diameter; DS-drum stick. S.E- Standard error of mean; C.O.V- Coefficient of variation.

Shank length, Shank diameter and Drum stick increased from $2.31 \mathrm{~cm}$ to $2.96 \mathrm{~cm}, 0.32$ to $0.44 \mathrm{~cm}$, and 3.04 to $5.16 \mathrm{~cm}$ between weeks two and eight, respectively. There was no significant effect $(P>0.05)$ of sex on most body measurements except for shank diameter and body girth (Table 2$)$. Female chicks had significantly higher $(P<0.05)$ shank diameter at the $2^{\text {nd }}(0.33 \mathrm{~cm})$ and $4^{\text {th }}(0.41 \mathrm{~cm})$ weeks of age and a higher body girth at the $6^{\text {th }}$ week. Sex effect on bodyweight was not significant $(P>0.05)$ at the $2^{\text {nd }}$ and $4^{\text {th }}$ weeks of age, although female quails were nominally better in mean bodyweight at these ages. However, Females were significantly higher $(P<0.05)$ than the males in body weight at $6^{\text {th }}(150.71 \mathrm{~g}$ vs. $127.62 \mathrm{~g})$ and $8^{\text {th }}(157.98 \mathrm{~g} v$ s. $130.10 \mathrm{~g})$ weeks of age. Coefficient of variation for body measurements was higher in males than in females but decreases with successive rearing age.

Table 2. Effect of sex on body weight and some linear measurements in the Japanese quail.

\begin{tabular}{|c|c|c|c|c|c|c|c|c|c|c|c|c|c|c|c|}
\hline \multicolumn{4}{|c|}{2 weeks } & \multicolumn{4}{|c|}{4 weeks } & \multicolumn{4}{|c|}{6 weeks } & \multicolumn{4}{|c|}{8 weeks } \\
\hline \multirow{2}{*}{$\frac{\mathrm{N}}{\text { Trait Mean }}$} & \multirow{2}{*}{$\frac{\text { Male }}{\mathrm{COV}}$} & \multicolumn{2}{|c|}{ Female } & \multicolumn{2}{|c|}{ Male } & \multicolumn{2}{|c|}{ Female } & \multicolumn{2}{|c|}{ Male } & \multicolumn{2}{|c|}{ Female } & \multicolumn{2}{|c|}{ Male } & \multicolumn{2}{|c|}{ Female } \\
\hline & & Mean & C.OV & Mean & $\mathrm{COV}$ & Mean & $\mathrm{COV}$ & Mean & $\mathrm{COV}$ & Mean & $\mathrm{COV}$ & Mean & $\mathrm{COV}$ & Mean & $\mathrm{COV}$ \\
\hline $\begin{array}{l}\text { BW } 34.51 \\
\text { (g) }\end{array}$ & 19.12 & 35.98 & 16.48 & 92.22 & 13.27 & 95.17 & 12.84 & $127.6^{\mathrm{b}}$ & 11.64 & $150.7^{\mathrm{a}}$ & 9.92 & $130.1^{\mathrm{b}}$ & 9.21 & $157.98^{\mathrm{a}}$ & 8.54 \\
\hline $\begin{array}{l}\text { BL } 11.78 \\
(\mathrm{~cm})\end{array}$ & 7.22 & 11.90 & 7.39 & 17.32 & 4.79 & 17.51 & 3.93 & 19.20 & 4.06 & 19.27 & 8.87 & 19.35 & 4.03 & 19.55 & 3.84 \\
\hline $\begin{array}{l}\text { BG } 8.09 \\
(\mathrm{~cm})\end{array}$ & 8.66 & 8.31 & 9.03 & 11.80 & 6.95 & 12.04 & 6.89 & $13.42^{\mathrm{b}}$ & 4.40 & $13.99^{\mathrm{a}}$ & 4.36 & 13.45 & 4.91 & 13.90 & 3.81 \\
\hline $\begin{array}{l}\text { WL } 5.83 \\
(\mathrm{~cm})\end{array}$ & 16.98 & 6.08 & 8.55 & 8.73 & 6.41 & 8.86 & 6.09 & 8.66 & 6.24 & 8.74 & 6.75 & 8.86 & 6.21 & 8.94 & 4.59 \\
\hline $\begin{array}{l}\text { SL } 2.31 \\
(\mathrm{~cm})\end{array}$ & 10.39 & 2.32 & 15.52 & 2.95 & 7.46 & 2.96 & 7.09 & 3.00 & 5.33 & 3.00 & 5.33 & 2.95 & 5.76 & 2.96 & 4.73 \\
\hline $\begin{array}{l}\mathrm{SD} 0.31^{\mathrm{b}} \\
(\mathrm{cm})\end{array}$ & 11.29 & $0.33^{\mathrm{a}}$ & 12.12 & $0.40^{\mathrm{b}}$ & 5.0 & $0.41^{\mathrm{a}}$ & 4.88 & 0.43 & 6.98 & 0.44 & 6.82 & 0.43 & 6.98 & 0.44 & 6.82 \\
\hline $\begin{array}{l}\text { DS } 3.02 \\
(\mathrm{~cm})\end{array}$ & 10.23 & 3.06 & 10.13 & 4.67 & 10.06 & 4.78 & 9.62 & 5.15 & 3.88 & 5.16 & 4.84 & 5.13 & 4.48 & 5.20 & 4.62 \\
\hline
\end{tabular}


Table 3 shows the correlation between body weight and body measurements in Japanese quail. Body weight was positive and significantly $(\mathrm{P}<0.01)$ correlated with all body measurements at $2^{\text {nd }}$ and $4^{\text {th }}$ weeks of age except for wing length $(0.35)$ at week four. Body Girth had the highest correlated value with body weight at $2^{\text {nd }}(0.70)$ and $4^{\text {th }}(0.68)$ weeks. At weeks six and eight, correlation coefficient had reduced for all body measurement except for BG. Estimates obtained for wing length, shank length and diameter and drum stick at weeks six and eight were between -0.01 and 0.27.

Table 3. Correlations between body weight and body measurements in the Japanese quail at different ages.

\begin{tabular}{lllll}
\hline \multirow{2}{*}{ Traits } & \multicolumn{4}{c}{ Body weight / age } \\
\cline { 2 - 5 } Body length & $0.66^{* *}$ & 4 weeks & 6 weeks & 8 weeks \\
Body girth & $0.70^{* *}$ & $0.45^{* *}$ & $0.26^{* *}$ & $0.39^{* *}$ \\
Wing length & $0.38^{* *}$ & $0.68^{* *}$ & $0.57^{* *}$ & $0.61^{* *}$ \\
Shank length & $0.45^{* *}$ & 0.35 & 0.12 & $0.25^{* *}$ \\
Shank diameter & $0.48^{* *}$ & $0.47^{* *}$ & $0.25^{*}$ & $0.27^{* *}$ \\
Drum stick & $0.28^{* *}$ & $0.36^{* *}$ & -0.01 & $0.19^{* *}$ \\
\hline
\end{tabular}

" significant at $P<0.05 ;{ }^{*}$ significant at $P<0.01$.

Table 4. Linear regression equation for predicting body weight at different ages in the Japanese quail.

\begin{tabular}{llllll}
\hline & Age & Intercept $(a)$ & $\begin{array}{l}\text { Regression } \\
\text { coefficient }(b)\end{array}$ & $\begin{array}{l}\text { Coefficient of } \\
\text { determination }\left(R^{2}\right)\end{array}$ & Results \\
\hline \multirow{3}{*}{ Body length } & 2 & -21.73 & 4.81 & 0.44 & $\mathrm{~S}$ \\
& 4 & -31.44 & 7.18 & 0.20 & $\mathrm{~S}$ \\
& 6 & 68.42 & 3.67 & 0.07 & $\mathrm{~S}$ \\
Body girth & 8 & -44.14 & 9.68 & 0.15 & $\mathrm{~S}$ \\
& 2 & -11.84 & 5.73 & 0.49 & $\mathrm{~S}$ \\
& 4 & -26.07 & 10.05 & 0.46 & $\mathrm{~S}$ \\
Wing length & 6 & -81.96 & 16.12 & 0.32 & $\mathrm{~S}$ \\
& 8 & -97.50 & 17.67 & 0.37 & $\mathrm{~S}$ \\
& & & & & $\mathrm{~S}$ \\
& 4 & 24.10 & 2.88 & 0.13 & $\mathrm{~S}$ \\
& 6 & 103.88 & 4.82 & 0.12 & $\mathrm{NS}$ \\
& 8 & 52.64 & 10.30 & 0.01 & $\mathrm{~S}$ \\
& & & & 0.06 & $\mathrm{~S}$ \\
& 2 & 13.37 & 9.46 & 0.20 & $\mathrm{~S}$ \\
& 4 & 14.74 & 26.74 & 0.22 & $\mathrm{~S}$ \\
\hline
\end{tabular}


Table 4 (contd.)

\begin{tabular}{llllll}
\hline Shank diam. & 2 & 11.47 & 75.0 & 0.23 & $\mathrm{~S}$ \\
& 4 & 18.45 & 185.01 & 0.13 & $\mathrm{~S}$ \\
& 6 & 142.22 & -7.53 & 0.00 & $\mathrm{NS}$ \\
Drum stick & 8 & 88.72 & 127.03 & 0.04 & $\mathrm{~S}$ \\
& 2 & 17.76 & 5.74 & 0.08 & $\mathrm{~S}$ \\
& 4 & 41.62 & 11.02 & 0.18 & $\mathrm{~S}$ \\
& 6 & 54.53 & 16.38 & 0.04 & $\mathrm{~S}$ \\
\hline
\end{tabular}

S- significant, NS-Not significant.

Tables 4 and 5 showed the linear and multiple regression equations and coefficient of determination $\left(R^{2}\right)$ for predicting body weight at different ages in the Japanese quail. Live body weight had a significant $(P<0.05)$ linear relationship with all body measurements at all ages except with wing length and the shank diameter at the sixth week of age.

$R^{2}$ was higest for BG at $2^{\text {nd }}(0.49)$ and $4^{\text {th }}(0.46)$ weeks and lowest for DS $(0.08)$ at the $2^{\text {nd }}$ and WL $(0.12)$ at the $4^{\text {th }}$ weeks. $R^{2}$ values reduced as the birds advanced in age. The $R^{2}$ values suggest that BG contributed 49 and 46 percent, BL contributed 44 and 20 percent to body weight at $2^{\text {nd }}$ and $4^{\text {th }}$ weeks, respectively. Conversely, wing length contributed as little as 0.13 and 0.12 percent to body weight at $2^{\text {nd }}$ and $4^{\text {th }}$ week. $R^{2}$ value increased when all body measurements were combined in a multiple regression with the body weight. $R^{2}$ value was $0.677,0.572,0.376$ and 0.414 at $2^{\text {nd }}, 4^{\text {th }}, 6^{\text {th }}$ and $8^{\text {th }}$ week, respectively.

Table 5. Multiple Regression Equations for estimating bodyweight at Different ages in the Japanese quail.

\begin{tabular}{|c|c|c|c|c|}
\hline $\begin{array}{l}\text { Age } \\
\text { (weeks) }\end{array}$ & Predicting equations & $R^{2}$ & Significance & $\begin{array}{l}\text { SE of } \\
\text { estimate }\end{array}$ \\
\hline 2 & $\begin{array}{l}Y=-38.02+2.31(\mathrm{BL})+3.51(\mathrm{BG})+0.85(\mathrm{WL})+5.15(\mathrm{SL}) \\
+11.54(\mathrm{SD})+(-1.12) \mathrm{DS}\end{array}$ & 0.677 & $* *$ & 3.68 \\
\hline 4 & $\begin{array}{l}Y=-106.20+2.49(\mathrm{BL})+7.35(\mathrm{BG})+1.81(\mathrm{WL}) \\
+9.49(\mathrm{SL})+39.83(\mathrm{SD})+1.88(\mathrm{DS})\end{array}$ & 0.572 & $* *$ & 8.25 \\
\hline 6 & $\begin{array}{l}Y=-79.78+0.98(\mathrm{BL})+15.08(\mathrm{BG})+1.65(\mathrm{WL})+25.08(\mathrm{SL}) \\
+1.04(\mathrm{SD})+0.63(\mathrm{DS})\end{array}$ & 0.376 & $* *$ & 15.30 \\
\hline 8 & $\begin{array}{l}Y=-171.18+1.89(\mathrm{BL})+16.78(\mathrm{BG})+6.45(\mathrm{WL}) \\
+14.68(\mathrm{SL})+(-80.63)(\mathrm{SD})+(-3.14)(\mathrm{DS})\end{array}$ & 0.414 & $* *$ & 14.89 \\
\hline
\end{tabular}

BW- body weight; BL- body length; BG-body girth; WL-wing length; SL-shank length; SD- shank diameter; DS-drum stick

**Coefficient of variation of $R^{2}$ is significant at $95 \%$ confidence level (i.e. $P<0.05$ ). 


\section{Discussion}

The result of the present study are in close agreement with the earlier findings of refs. $[16,17]$ who reported that the age is a major determinant of growth and physiological development. The body weight and linear measurements obtained in this study were however lower than values reported by other authors[18-21].This is not unexpected in morphometric traits assessments of birds belonging to different populations [22]. The coefficient of variation for morphometric traits suggest that there was an increased uniformity in body size measurements as the birds advance in age, especially among the female quails. Sexual dimorphism has previously been reported in favour of the male in duck [23], pigeon [24], and pheasants [25, 26]. The growth pattern of male and female Japanese quails raised in other environments have been well documented [20, 27-29]. The growth pattern observed in the present study agrees with the pattern reported in refs. [20] and [29]. For example, it was reported in ref. [20] that there were no sex differences in hatchling weight and that the degree of sexual dimorphism was low until after 4 weeks of age.

The findings of present study on correlation between body weight and linear measurements are in line with previous reports of refs. [8, 23, 24, 30]. Ibe and Nwakalor [30] reported high and positive correlations between linear measurements and body weight in the Nigerian local chicken. The same was reported in refs. [8] and [24] in their studies on broiler chicken and pigeon, respectively. A zoometric study on Nigerian local Muscovy ducks in ref. [23] also showed highly significant positive correlations between body weight and zoometric body measurements. Raji et al. [23] observed that chest girth had the strongest correlation with body weight followed by body length. The strong correlation between chest girth and body weight may be due to the fact that the chest girth consists of important bones, muscles and viscera. The present study indicates that DS and WL are less strong compared with SL and BG as indicators of body weight in the Japanese quail. Raji et al. [11] reported that shank length and diameter were good indicators of leg development. The present result on correlation between body weight and wing length in Japanese quail contradicts the earlier report by Teguia et al. [31] who reported highest correlation between body weight and wing length in Muscovy duck. The disparity may be due to the fact that Muscovy duck has extensively developed wings which are used for both flight and incubation. According to a report on Muscovy duck [23], the highest $R^{2}$ value (0.728) was obtained when chest girth was used singly, followed by body length and wing length. The increment in $R^{2}$ values when all body measurements were combined in a multiple regression with the body weight support the earlier results of refs. [10, 23] who observed an increase in coefficient of determination in local chicken and Muscovy duck (respectively) when body measurements like chest girth, body length and chest width were combined in a multiple regression. 


\section{Conclusion}

The results of this study shows that body weight in Japanese quail is linearly related to body measurements, especially with BG and BL. The prediction of body weight from these measurements is therefore possible as early as 2 weeks of rearing. Therefore, a breeding programme to achieve an optimum combination of body weight and good conformation for maximum economic returns in the Japanese quail can be easily organized using easily measured parts like BG and BL.

\section{References}

1. F. Minvielle, Proceedings in the $6^{\text {th }}$ Asian Pacific poultry congress, (Nagoya, Japan, 1998) pp 481.

2. U. Musa, E. S. Haruna and L. H. Lombin, Quail Production in the Tropics (NVRI Press, Vom, 2008).

3. F. Minvielle, Worl. Poult. Sci. J. 60, 500-507 (2004). http://dx.doi.org/10.1079/WPS200433

4. A. A. Odunsi, A. Rotimi and E. A. Amao, World Applied Sci. Journal 3 (5), 567-577 (2007). http://www.idosi.org/wjas/wjas3\%285\%29/2.pdf

5. A. O. Raji, A. J. Abdulkarim, B. Mohamed, S. A. Yunus, , A. N. Ezuma and P. U. Nkoloagu, Proceedings in the $13^{\text {th }}$ ASAN conference, ABU Zaria, Nigeria (2008) pp. 40-42.

6. G. E. S. Robins, Quail, their breeding and management (World Pheasant Association, UK, 1981).

7. National Research Council, Microlivestock (National Academic Press, Washington DC, 1991). http://www.nap.edu/openbook.php?record_id=1831\&page=R1

8. F. O. Adeniji and K. L. Ayorinde, Nig. J. Anim. Prod. 17, 42 (1990).

9. G. Pesmen and M. Yardimci, Archiva Zootechnica 11(4), 30 (2008). http://www.ibna.ro/arhiva/AZ\%2011-4/AZ\%2011-4\%2003\%20Pesmen\%20\%20Yardimci.pdf

10. O. M. Momoh, and D. E. Kershima, Asset Series A 8 (2), 206 (2008). http://journal.unaab.edu.ng/index.php/Series_A/article/view/82

11. J. Maciejowski, and T. Zeiba, Part B. Stock improvement Methods (Elsevier Scientific Publishing Company, Amsterdam, 1982).

12. J. P. Semakula, D. R., Lusembo, D. Kugonza, J. Mutetikka, J. S. Sennyonjo and M. Mwesigwa, Liv. Res. for Rural Devpt. 23, 170 (2011). http://www.lrrd.org/ lrrd23/8/sema23170.htm

13. C. A. Chineke, B. Agaviezor, C. O. N. Ikeobi and A. G. Ologun, Proceedings in the $27^{\text {th }}$ Annual Conference of Nigeria Society for Animal Production, FUT Akure, Nigeria, (2002) pp 1-3.

14. V. Ojo, K. L. Ayorinde, S. A. O. Bolu and O. I. Alli, Agrosearch 11 (1\&2), 63 (2011). http://www.ajol.info/index.php/agrosh/article/view/75059

15. SPSS, Statistical Package for Social Sciences (SPSS inc., Chicago, 1996).

16. E. B. Sonaiya, A. R. Williams and S. A. Oni, J. Anim. Prod. Res., 691, 73 (1986).

17. L. O. Ojedapo, S. R. Amao, S. A. Ameen, T. A. Adedeji, R. I. Ogundipe and A. O. Ige, Asian J. of Anim. Sci. 6 (1), 13-22 (2012). http://scialert.net/fulltext/?doi=ajas.2012.13.22\&org=12

18. M. I. M. Almeida, E. G. Oliviera, P. R. Ramos, N. Viega and K. Dias, Archiv. Vet. Sci. 7 (2), 103-108 (2002). http://ojs.c3sl.ufpr.br/ojs2/index.php/veterinary/article/viewFile/3988/3228

19. J. M. Reddish, K. E. Nestor and M. S. Lilburn, Poult. Sci. 82, 187 (2003). http://www.ncbi.nlm.nih.gov/pubmed/12619793

20. M. E. Sezer, E. Berberoglu and Z. Ulutas, S. Afr. J. Anim. Sci. 36 (2), 142 (2006). www.ajol.info/index.php/sajas/article/download/3997/11939

21. A. Tulobaev, H. Alpak, D. Bektemirova, and A. Turdubaeva, Turk. J. Vet. Anim. Sci. 36, 4 (2012) http://mistug.tubitak.gov.tr/bdyim/abs.php?dergi=vet\&rak=1102-781

22. O. J. Alabi, J. W. Ng ambi, D. Norris and S, S. A. Egena, Agric. J. 7 (3), 220 (2012). http://docsdrive.com/pdfs/medwelljournals/aj/2012/220-225.pdf 
23. A. O. Raji, J. U. Igwebuike, and M. T. Usman, ARPN J. Agric. Biol. Sci. 4 (3), 58 (2009). http://www.arpnjournals.com/jabs/research papers/rp 2009/jabs 0509 135.pdf

24. W. A. Hassan, U. A. Adamu, INFPD Workshop and General Meeting 9-13 December, M'Bour Senegal (1997)

25. J. Kuzniaka, and M. Adamski, Archiv Tierzucht 53 (3), 360 (2010) http://arch-anim-breed.fbn-dummerstorf.de/pdf/2010/at10p360.pdf

26. M. T. Górecki, S. Nowaczewski, and H. Kontecka, Folia boil. (Kraków), 60 (1-2) , 79 (2012) http://www.isez.pan.krakow.pl/journals/folia/pdf/60(1-2)/60(1-2)_14.pdf

27. M. S. Balcıoglu, K. Kızılkaya, H. İ Yolcu and K. Karabăg, S. Afr. J. Anim. Sci. 35, 83 (2005).

28. M. Sezer, and S. Tarhan, Czech. J. Anim. Sci. 50, 22 (2005). http://www.cazv.cz/service.asp?act=print \&val=32649

29. J. Hort, L. Hyankova and H. Knizetova, Proc. Poult. Gen. Symp., Mariencee, Germany, (1999) p. 120.

30. S. N. Ibe and C. N. Nwakalor, Poult. Sci. 66, 1274 (1987). http://www.ncbi.nlm.nih.gov/pubmed/3684846

31. A. Teguia, H. Mafouo Ngandjou, H. Defang, and J. Tchoumboue, Trop. Anim. Health and Prod. 40, 5 (2008). http://link.springer.com/article/10.1007\%2Fs11250-007-9030-4 